ONE HUNDRED AND SIXTY-SEVENTH SCIENTIFIC MEETING SEVENTIETH SCOTTISH MEETING

PHYSIOLOGY LECTURE 'THEATRE, QUEEN'S COLLEGE, DUNDEE

I 2 SEP'TEMBER 1964

\title{
MAJOR ELEMENTS IN NUTRITION
}

\author{
Chairman: C. F. Mills Esq., MSc, PhD, FRIC, Rowett Research Institute, \\ Bucksburn, Aberdeen
}

Variations of strength of vertebras with age

By G. H. Bell, Queen's College, Dundee, University of St. Andrezs

Text for publication not received.

\section{Calcium intake and calcium requirement of man}

\author{
By B. E. C. Nordin, University of Leeds
}

Text for publication not received.

\section{Calcium-endocrine relationships in the laying hen}

By T. G. TAYLOR, Department of Physiological Chemistry, University of Reading

The frontier area between nutrition and endocrinology presents some fascinating and complex problems, and in this paper I should like to deal with one small sector of this region as it affects one particular species.

The intensity with which the laying hen metabolizes calcium is well recognized. A typical bird laying at the rate of six eggs per week, by no means an exceptional performance for a modern hen, secretes in the shells of these eggs at least $10 \mathrm{~g} \mathrm{Ca}$, as the carbonate. This performance appears all the more impressive when it is remembered that the entire body of the average laying hen contains only $20-25 \mathrm{~g} \mathrm{Ca}$. The immediate source of this $\mathrm{Ca}$ is the blood and the ultimate source is the food; the skeleton acts as a buffer, storing $\mathrm{Ca}$ when it is absorbed from the gut at a rate greater than that at which it is required for shell calcification and releasing it into the circulation when the rate of absorption is less than the rate of utilization by the shell gland. The rate at which skeletal $\mathrm{Ca}$ can be mobilized for egg-shell formation when dietary supplies are inadequate is truly phenomenal. If a hen is fed on a diet very deficient in $\mathrm{Ca}$ on one morning, the egg that is laid $24 \mathrm{~h}$ later will look quite normal, but its shell will be slightly thinner than usual and it will probably contain about 10\% less $\mathrm{Ca}$ than the average for that particular bird. Such an egg might therefore contain $\mathrm{I} \cdot 8 \mathrm{~g} \mathrm{Ca}, 7-9 \%$ of the total body content.

The process of egg-shell formation occupies about $20 \mathrm{~h}$ but the rate of $\mathrm{Ca}$ deposition is slow for the first 5 h or so (Warren \& Scott, I935; Burmester, Scott \& Card, I939; Bradfield, I95I), and the main period of shell calcification lasts, therefore, about $15 \mathrm{~h}$. This means that the fowl is capable of mobilizing Ca from the 
skeleton at the rate per $\mathrm{h}$ of $\mathrm{I} 20 \mathrm{mg}$, an amount equivalent to something like five times the amount present in the blood, so that a weight of Ca equal to the quantity circulating in the body is withdrawn from the skeleton and laid down on the calcifying egg-shell every $12 \mathrm{~min}$.

It is only under experimental conditions that the domestic fowl is called upon to mobilize bone $\mathrm{Ca}$ at this rate, but wild birds living in lime-deficient areas, whose normal diet is low in $\mathrm{Ca}$, are entirely dependent on their skeletal reserves for egg-shell formation as a normal condition of life. The demands that are liable to be made on the skeletons of female birds during reproduction are so great that a specialized type of secondary bone has been developed during the course of evolution to provide the Ca necessary for shell formation. This secondary bone is known as medullary bone and it occupies the marrow cavities of most of the bones of the skeleton. It grows out from the endosteal surfaces of the bones in the form of fine interlacing spicules which penetrate the red marrow which normally occupies the marrow cavities, leaving the vascular pattern apparently unchanged.

Medullary bone develops in pullets IO-I 4 days before the first egg is laid and it persists throughout the whole of the laying season. It is formed under the combined influence of male and female sex hormones and it may be induced in cocks by oestrogen treatment. When immature pullets are injected with both oestrogen and androgen the retention of calcium and phosphorus from the food increases considerably, often reaching the levels observed in pullets coming into lay naturally, but neither hormone alone influences mineral retention appreciably (Common, Rutledge \& Hale, I948).

The magnitude of the effect of sex hormones on increasing the retention of $\mathrm{Ca}$ and $\mathrm{P}$ is of the order of tenfold in pre-laying pullets. Just before the onset of sexual maturity $\mathrm{Ca}$ is being retained at a mean rate of rather less than $100 \mathrm{mg} /$ day, whereas values as high as $750 \mathrm{mg} /$ day have been recorded in the immediate pre-laying period (Taylor \& Moore, 1954, unpublished observations). It has not been shown experimentally that the increased retention of minerals in pre-laying pullets and in birds treated with a combination of oestrogens and androgens is due to increased absorption from the gut, but it has been demonstrated that laying hens absorb more $\mathrm{Ca}$ on laying than on non-laying days (Fussell, I960) and it seems reasonable to suppose that a similar mechanism is involved in all these situations. The parathyroid gland of pullets enlarges during the pre-laying period (Macowan, I93I-2) and it may well be concerned in stimulating Ca absorption at this time and, subsequently, during the laying period.

It is the medullary bone that is first broken down to provide the Ca for egg-shell formation when dietary supplies are inadequate, and the extreme lability of this bone is most probably related to the large surface area of its spicules and to its high vascularity. Continued egg production on a Ca-deficient diet results in the resorption of structural bone. The first bones to suffer are the flat bones, the ribs, sternum and the bones forming the pelvic girdle. As $\mathrm{Ca}$ depletion continues, the cortex of the femur, tibia, coracoid and wing bones is resorbed and, finally, the vertebras, scapula and clavicle become eroded. Certain bones, particularly the skull, metatarsus and 
humerus, are very resistant to resorption. The extent to which the skeleton of the domestic fowl can be mobilized to provide Ca for egg-shell formation is quite remarkable: in one particular experiment birds which had laid six eggs on a low-Ca diet were found to have lost almost $40 \%$ of the skeletal mass present at the beginning of the low-Ca régime (Taylor \& Moore, r954).

There is no reason to doubt that the parathyroid hormone is responsible for the resorption of both medullary and cortical bone under these circumstances. The parathyroid glands of birds laying on a Ca-deficient diet are generally enlarged and the histological changes occurring in the bone tissue are typical of those observed in hyperparathyroidism.

All the evidence suggests that the mobilization of skeletal Ca for egg-shell formation is a normal physiological process, even when dietary supplies of Ca are adequate. This has perhaps been demonstrated most convincingly in an autoradiographic study of ground sections of egg-shells laid by birds fed with ${ }^{45} \mathrm{Ca}$ (Tyler, 1954). It was concluded from this experiment that there is a period in the early hours of the morning between the time when absorption of dietary Ca from the previous day's food ends and absorption from the current day's food begins when $\mathrm{Ca}$ for shell formation comes largely from the skeleton. This conclusion is supported by the results of histological studies of the medullary bone of laying hens at different stages of egg-shell calcification (Bloom, Domm, Nalbandov \& Bloom, 1958; Stringer, 1962). In the early stages of shell formation, which occur mainly during the afternoon and evening when $\mathrm{Ca}$ is being absorbed from the gut in large amounts, both osteoblasts and osteoclasts are abundant, whereas in the advanced stages of shell calcification, when supplies of dietary $\mathrm{Ca}$ are failing, the bone trabeculae are surrounded by large numbers of osteoclasts and osteoblasts are rare. In the pigeon the changes that occur in the cell population of the medullary bone during egg-shell formation are even more striking than those that occur in the domestic hen. In the pigeon, periods of intense bone destruction (when shell calcification is in progress) alternate with periods of equally intense bone formation (before and after calcification of the first egg-shell of the two-egg clutch) and the change from one phase to the other occurs extremely rapidly (Bloom, Bloom \& McLean, 194I).

The cause of the onset of the bone-destroying phase, clear-cut in the pigeon, rather less well defined in the hen, has not been established, but it is interesting to speculate as to the possible factors involved. Riddle, Rauch \& Smith (1945), Urist (I959) and Urist, Deutsch, Pomerantz \& McLean (I960) have suggested that, since medullary bone requires a constant oestrogenic stimulation for its maintenance, fluctuations in the blood level of oestrogen are responsible for the histological changes in the medullary bone during the egg cycle.

An alternative explanation is that the changes in the cell population of the medullary bone are due to changes in parathyroid activity, and a number of experimental observations support this theory:

(a) The rapidity with which the changes occur. (Hertelendy (r962) has shown that the maximum response to an intravenous injection of a parathyroid preparation occurs after $2 \mathrm{~h}$ in the fowl.) 
(b) The resemblance between the histological picture observed in medullary bone at the height of egg-shell calcification and in bone under the influence of parathyroid hormone.

(c) The prerequisite conditions for parathyroid stimulation, namely a fall in the level of diffusible $\mathrm{Ca}$ in the blood, has been demonstrated during egg-shell formation (Taylor \& Hertelendy, I96r).

An added attraction of this view is that it does not require separate mechanisms to explain bone resorption under normal dietary conditions and under conditions of $\mathrm{Ca}$ deprivation.

Nothing is known of the possible involvement in egg-shell formation of calcitonin (Copp, Cameron, Cheney, Davidson \& Henze, I962; Copp, 1964), the new parathyroid hormone that lowers plasma $\mathrm{Ca}$, or, indeed, if this hormone is produced in birds.

An interesting relationship has recently been established in the laying hen between Ca metabolism and the anterior pituitary gland (Taylor, Morris \& Hertelendy, I962). When hens are fed on a Ca-deficient diet they normally stop laying after Io-I 4 days, having laid, perhaps, six to eight eggs on the deficient diet, and we thought it would be of interest to investigate the mechanism by which the cessation of lay is brought about. Failure to lay is obviously due to failure to ovulate, for once ovulation occurs the process of egg formation proceeds inexorably and an egg is laid, with or without a shell. The question then becomes, 'why does ovulation cease when hens are deprived of Ca', and the most reasonable answer seemed to be that the level of gonadotrophin secretion by the anterior pituitary is reduced in these circumstances. To test this hypothesis six Rhode Island Red $\times$ Light Sussex pullets which had been in lay about a month were transferred from a high-Ca $(3 \%)$ to a low-Ca $(0 \cdot 2 \%)$ diet, and five control birds were maintained on the high-Ca diet. Daily injections of an extract of crude avian pituitary glands were administered to three of the birds on the low-Ca and two on the high-Ca diet beginning on the $5^{\text {th }}$ day after the deficient diet was introduced.

One of these injected birds became paralysed after 9 days on the deficient diet and was killed shortly after the signs appeared. The remaining birds on the low-Ca diet were killed I 5 days after the experiment began, at which time the two surviving injected pullets were in a very weak condition. Birds on the high-Ca diet were killed on the $17^{\text {th }}$ day.

The three control pullets on the high-Ca diet laid 7,8 and I I eggs in 17 days and the two injected birds laid I 3 and 15 eggs in the same period. Details of egg production by the low-Ca pullets are given in Table I. The Ca-deficient birds treated with pituitary material each laid an egg every day for at least 5 days after the first injection, although egg production by the Ca-deficient controls had virtually ceased at this stage.

It appears therefore that the failure of egg production which occurs when hens are fed on a Ca-deficient diet is due to the failure of gonadotrophin secretion by the anterior pituitary. The mechanism by which the pituitary is inhibited has not been 
Table I. Egg production by hens injected with an extract of avian pituitary and by control hens all fed on a low-calcium $(0.2 \%)$ diet from day $\mathrm{I}$

$\begin{array}{cccc}\begin{array}{c}\text { Bird } \\ \text { no. }\end{array} & \text { Days I-5 } & \begin{array}{c}\text { No. of eggs laid } \\ \text { Days 6-10 } \\ \text { Controls }\end{array} & \text { Days I I-I5 } \\ \text { I6 } & 4 & \text { I } & 0 \\ \text { I7 } & 3 & 3 & \text { I } \\ \text { I9 } & 4 & \text { I } & 0 \\ & & \text { Injected } & \\ 2 \text { I } & 3 & 5 & \text { I } \\ 27 & 4 & 5 & \text { (Dead) } \\ 28 & 4 & 6 & 4\end{array}$

Table 2. Levels of total and diffusible calcium $(\mathrm{mg} / 100 \mathrm{ml})$ in the plasma of hens injected with an extract of avian pituitary and of control hens fed on a high-or low-Ca diet

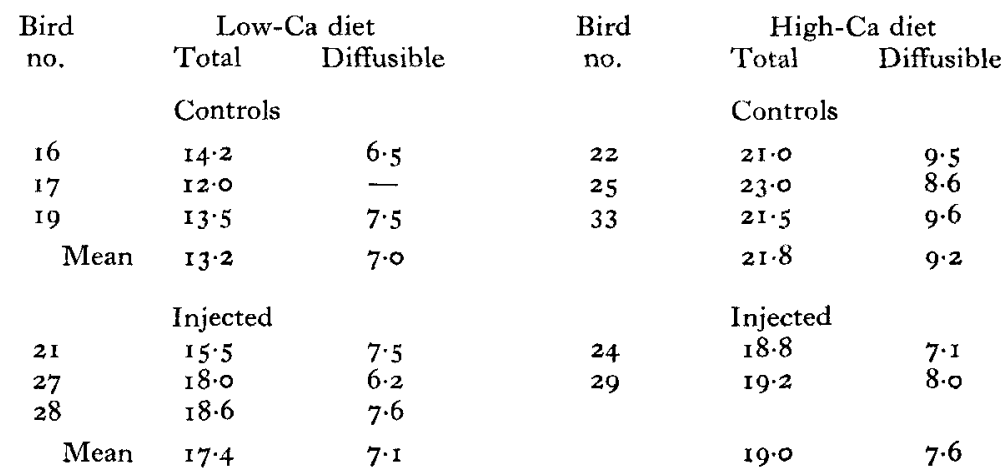

established, but it is possible that the hypothalamic stimulation of the pituitary is reduced by the fall in the diffusible Ca level of the blood (Table 2 ).

The inhibition of pituitary gonadotrophin secretion under conditions of serious Ca deficiency may be looked upon as a protective mechanism, which prevents excessive depletion of the skeleton. The sensitivity of this mechanism is variable and in high-producing birds the mechanism appears to be relatively insensitive at the onset of reproduction when gonadotrophin secretion is sufficiently high to produce more than one ovulation per $24 \mathrm{~h}$ period. In one experiment (Taylor et al. 1962) six very prolific pullets all collapsed within ro days when placed on a low-Ca diet and some of them continued to lay even when completely prostrate in their cages.

This 'pituitary cut-off mechanism' may well be a factor in determining the level of egg production in hens. If there is a critical level of diffusible plasma $\mathrm{Ca}$ below which the cut-off mechanism is brought into play, it is possible that this level is reached in some birds during egg-shell calcification even when a high-Ca diet is given. The effect would be to reduce gonadotrophin secretion, which would in turn reduce the rate of follicle growth and the rate of oestrogen secretion, the combined effect of which would be a fall in the ovulation rate. The fall in oestrogen secretion would be expected to stimulate the resorption of medullary bone, as envisaged by 
Riddle et al. (r945) and Urist (1959). The mean level of diffusible Ca in the plasma during egg-shell calcification is about $8.4 \mathrm{mg} / 100 \mathrm{ml}$, but in some individuals it may fall to $7.6 \mathrm{mg} / 100 \mathrm{ml}$, and there is no reason to believe that this latter figure represents a minimum (Taylor \& Hertelendy, 196r).

It may be claimed with some justification that the laying capacity of a hen is directly related to her ability to absorb and metabolize $\mathrm{Ca}$, and these functions are largely under hormonal control. Nutrition and endocrinology are in fact so closely interrelated in the $\mathrm{Ca}$ metabolism of the laying hen that they cannot be considered separately with any degree of understanding.

\section{REFERENCES}

Bloom, M. A., Domm, L. V., Nalbandov, A. V. \& Bloom, W. (1958). Amer. F. Anat. ro2, 4 I I.

Bloom, W., Bloom, M. A. \& McLean, F. C. (1941). Anat. Rec. 81, 443.

Bradfield, J. R. G. (195 I). F. exp. Biol. 28, 125.

Burmester, B. R., Scott, H. M. \& Card, L. E. (1939). World's Poult. Congr. vil, Cleveland, Ohio, p. 99.

Common, R. H., Rutledge, W. A. \& Hale, R. W. (1948). F. agric, Sci. 38, 64.

Copp, D. H. (1964). Recent Progr. Hormone Res. 20, 59.

Copp, D. H., Cameron, E. C., Cheney, B. A., Davidson, A. G. F. \& Henze, K. G. (1962). Endocrinology, 70,638 .

Fussell, M. H. (1960). Studies on calcium and phosphorus metabolism in the hen. Ph.D. Thesis, University of Cambridge.

Hertelendy, F. ( 1962 ). Biochemical studies on the tissues of the domestic fowl in relation to reproduction. Ph.D. 'Thesis, University of Reading.

Macowan, M. M. (x93 I-2). Quart. F. exp. Physiol. 21, 383 .

Riddle, O., Rauch, V. M. \& Smith, G. C. (1945). Endocrinology, 36, 4 I.

Stringer, D. A. (1962). The chemistry and physiology of bone, with special reference to medullary bone in the fowl. Ph.D. Thesis, University of Reading.

Taylor, T. G. \& Hertelendy, F. (I961). Poult. Sci. 40, I 5.

Taylor, T. G. \& Moore, J. H. (I954). Brit. F. Nutr. 8, i I 2.

Taylor, T. G., Morris, T. R. \& Hertelendy, F. (1962). Vet. Rec. 74, 123.

Tyler, C. (1954). F. Sci. Fd Agric. 5, 335.

Urist, M. R. (I959). Recent Progr. Hormone Res. 15, 455.

Urist, M. R., Deutsch, N. M., Pomerantz, G. \& McLean, F. C. (1960). Amer. F. Physiol. 199, 85 I.

Warren, D. C. \& Scott, H. M. (1935). Poult. Sci. 14, 195.

\section{The importance of hypocalcaemia in the development of hypomagnesaemic tetany}

By R. G. Hemingway and N. S. Ritchie, Department of Animal Husbandry and Preventive Veterinary Medicine, Glasgow University Veterinary School, Bearsden, Glasgow

It is generally considered that the normal concentration of magnesium in the blood plasma of cattle is within the range $2 \cdot 0-2 \cdot 5 \mathrm{mg} / \mathrm{I} 00 \mathrm{ml}$. Allcroft (1947a) has defined hypomagnesaemia as being associated with concentrations below $1 \cdot 7 \mathrm{mg}$ $\mathrm{Mg} / \mathrm{I} 00 \mathrm{ml}$. Rook \& Balch (1958) regarded $\mathrm{r} \cdot 8 \mathrm{mg} \mathrm{Mg} / \mathrm{I} 00 \mathrm{ml}$ as the lower limit of the normal range, and Butler ( 1963 ) designated concentrations of $\mathrm{Mg}$ below $\mathrm{I} \cdot 8$ $\mathrm{mg} / 100 \mathrm{ml}$ as hypomagnesaemic. Many other authorities would accept this value of $\mathrm{I} \cdot 7^{-1} \cdot 8 \mathrm{mg} / \mathrm{I} 00 \mathrm{ml}$ as being the lower limit of the normal range. Hypomagnesaemia is not however synonymous with clinical tetany. Although Butler (1963) recorded an $8.7 \%$ incidence of hypomagnesaemia $(<\mathrm{I} .8 \mathrm{mg} \mathrm{Mg} / 100 \mathrm{ml}$ ) in a survey covering 